\title{
Tektites and microtektites iron oxidation state and water content
}

\author{
Gabriele Giuli $^{1}$ (D)
}

Received: 27 February 2017 / Accepted: 3 October 2017

(C) Accademia Nazionale dei Lincei 2017

\begin{abstract}
Fe redox and water content of impact melt are important parameters as they can greatly affect melt density and viscosity which, in turn, are important parameters greatly affecting the melt evolution and fate. In this manuscript I briefly describe recent research on X-ray absorption spectroscopy (XAS) determination of Fe oxidation state and micro Fourier transform infrared spectroscopy (FTIR) determination of water content putting them in the context of previous research done with different techniques. In comparison with other techniques requiring large amount of samples (e.g. potassium dichromate titration, Mossbauer spectroscopy, Karl Fischer titration), XAFS and micro FTIR techniques allow to study both macroscopic samples of tektites as well as smaller microtektites giving the same error, making it possible to compare results between tektites and micro-tektites and, consequently, also to find differences between tektites and microtektites or between microtektites from different strewn fields. A brief introduction on impact cratering and melt formation during impact events is aimed to introduce the subject to non specialised readers.
\end{abstract}

Keywords Impact melt $\cdot$ Tektite $\cdot$ Microtektite

This contribution is the written, peer-reviewed version of a paper presented at the Conference "Mineral phases and synthetic analogues in Earth and Materials science", held at the Accademia Nazionale dei Lincei in Rome on June, 13-14, 2016.

Gabriele Giuli

gabriele.giuli@unicam.it

1 Scuola di Scienze e Tecnologie-sez. Geologia, Università di Camerino, Via Gentile III da Varano, 62032 Camerino, MC, Italy

\section{Introduction}

Silicate melt properties like structure, volatiles content and redox state of transition elements are important factors controlling nucleation and growth of mineral phases, partition coefficients of minor and trace elements, as well as melt density and viscosity. Thus, these properties are able to affect the chemical and mineralogical evolution of the melt itself during crystallization. The knowledge of the relationships between these parameters is the key to understand the conditions under which a melt forms and evolves in nature. On the other side, these data could be used to model processes and properties of melts/glasses for technological applications.

While most studies of silicate melts in Earth sciences aim to understand and/or model magmatic processes, relatively fewer studies are devoted to understanding the production and fate of melts formed during asteroid impacts on the Earth surface. Impact cratering can produce vast amounts of melt which can be either ejected away from the crater or collected inside the crater to form coherent melt bodies with thicknesses up to several kilometers. In recent years, it is becoming increasingly clear that impact processes were able to greatly affect the evolution of planetary bodies. In the specific case of the Earth these processes were able to profoundly affect the geochemical evolution of the Earth crust, as well as the atmosphere and life itself.

The investigation of impact products and their synthetic analogues produced under extreme conditions suggests that target rocks can experience significant chemical and physical transformations during impact melting. Fe redox and water content of impact melt are important parameters as they can greatly affect melt density and viscosity.

As density and viscosity of an impact melt are important parameters greatly affecting the melt evolution and fate, in this contribution I will present a review of the current 
knowledge about melt formation by impact cratering and discuss the results recently obtained on the Fe speciation and water content in tektites and microtektites. As a first step in order to investigate the iron oxidation state and water content of impact melt, it is convenient to focus our attention to tektites and microtektites: they display a relatively homogeneous composition within a given strewn field; are representative of the melting of the uppermost part (and most shocked) of the target rock; have been quickly cooled forming an homogeneous glass. Impact glasses sensu latu, on the other hand, may have had an even more complex thermal history and alteration history, suffer projectile contamination, or result from melting of different rocks types placed at different depths in the Earth's crust (see for example Koeberl and Sigurdsson 1992; Stöffler et al. 2013; Artemieva et al. 2013; Ritter et al. 2015; Giuli et al. 2003, 2005, 2008) and will not be treated in this contribution.

\section{Impact cratering as a geological process}

Hypervelocity impacts of asteroids or comets on planetary surfaces produce distinctive shock-metamorphic and shockmelting effects ranging from fracturing to melting, including formation of high pressure phases, microscopic deformation features, diaplectic glasses, or macroscopic features such as shatter cones (see French 1988). These features (also called "shock effects" or "shock features") have been critical to the identification of terrestrial impact structures and offer a window for studying the extreme conditions experienced by the target rocks during impacts (see French 1988; Montanari and Koeberl 2000; Koeberl and Martinez-Ruiz 2003 and references therein). Among the geological processes that have been (and are still) affecting the planetary surfaces in our Solar System, impact cratering can lay claim to being ubiquitous (Gibson and Reimold 2010). However, the study of the effect of asteroidal or cometary impact onto a target rock (known as shock metamorphism) is only a recent discipline. Systematic studies of lunar surface images and of terrestrial craters prompted by the race for the Moon in the 1960s delivered the first quantitative morphological datasets on impact craters (e.g., Shoemaker 1962). Taking advantage from studies of shock wave phenomena observed in nuclear explosions, scientists started turning their attention to understanding the processes of rock deformation and phase transformations involved in impact cratering (e.g., French and Short 1968). By the late 1970s scientists already possessed a range of experimentally constrained data on phase transformations and shock deformations, which could be profitably used to test the impact origin of craters on the Earth surface or on the Moon (e.g., Stoffler and Langenhorst 1994; Grieve et al. 1996).
The detailed shock-metamorphism experimental database, as well as cataloging of field and microscopic shock features, led to the identification of new terrestrial impact structures at a rate of two to three per year during the 1970s-1990s, with the consequence that the database grew from a mere dozen in 1960 to more than 150 structures by the mid-1990s. By this time, the identification of the globally-distributed extraterrestrial iridium anomaly in the Cretaceous-Tertiary (K-Pg) boundary layer and the establishment of a link between the end-Cretaceous mass extinction event and the large Chicxulub impact structure in Mexico (e.g., Koeberl and MacLeod 2002; Schulte et al. 2010, and references therein) provided global awareness of the devastating planetary-scale environmental effects of large impacts. As for now, about 190 confirmed terrestrial impact craters or impact structures are known (see http://www.passc.net/ EarthImpactDatabase/gow.html for an updated list of terrestrial impact craters), with ages ranging from 2020 Ma to just 10 years (the Carancas crater, a $13 \mathrm{~m}$ wide feature formed in 2007 after the fall of a small meteoroid).

\section{Melt formation}

A remarking feature of impact processes is the almost instantaneous melting and vaporisation of significant amounts of the target rock, in the vicinity of the projectile contact point, along with the onset of shock induced phase transformations, rock fracturing, and crater excavation. The produced impact melt can be distributed either in proximity of the impact crater, either can be ejected at high speed away from the crater (Melosh 1989). The dynamic of crater formation determines the distribution of melt: the uppermost part of the target rock, which is also subjected to the highest pressures and temperatures can, in particular conditions, be ejected at supersonic speed away from the crater. Rapid cooling of these melts produces silicate glasses, called tektites and microtektites, which can be distributed over wide areas called strewn fields and can extend up to several hundreds or thousands of kilometers away from the source crater (see Koeberl 1994; Ma et al. 2004; Koeberl et al. 2015 and references therein; for consideration on the derivation of tektite and microtektite forming melt from the topmost target surface). Most of the produced melt however is deposited in or near the impact crater. It may form coherent impact melt bodies or can be mixed with shattered brecciated material to form suevitic breccias. Impact melt is a significant component of the rocks produced by the cratering event, especially in large impact structures, and its volume increases at increasing size of the crater (Dence 1971; Grieve and Cintala 1992; Pierazzo and Melosh 2000; Stöffler et al. 2013; Artemieva et al. 2013). 
Although most of the material (about 90 vol\%) ejected from the crater is deposited relatively close $(<5$ crater radii, Rc) to the crater (Melosh 1989, p. 90), a significant amount (about 10 vol\%) may travel to even greater distances ( $>5$ $\mathrm{Rc})$ to form deposits of distal ejecta. Where an atmosphere is present, as in terrestrial impact events, a combination of disruption of the atmosphere by the impact fireball, ballistic ejection from the crater, and subsequent atmospheric transport can distribute the smaller ejecta particles (typically $>1 \mathrm{~mm}$ ) to regional or even global distances (Alvarez et al. 1995). The resulting deposits, usually less than a few centimeters thick, may contain distinctive evidence for impact: shocked rock and mineral fragments, distinctive chemical and isotopic signatures, and unusual glassy objects. It has thus become possible to recognize debris from a given impact structure over a large area of Earth, and even to establish the existence of a major impact event from a globally distributed ejecta layer before the structure itself could be located.

\section{Iron oxidation state of tektites and microtektites}

Tektites are natural silicate glasses that occur in geographically limited areas, called strewn fields (Fig. 1). They differ from common volcanic glasses in both chemical and physical properties (Suess 1900; O’Keefe 1976; Koeberl 1986,
1994; Glass 1990). Their characteristic features include high silica and very low water content, the presence of lechatelierite (amorphous $\left.\mathrm{SiO}_{2}\right)$ particles, and a low $\mathrm{Fe}^{3+} /\left(\mathrm{Fe}^{2+}+\mathrm{Fe}^{3+}\right)$ ratio (Fudali et al. 1987; Dunlap et al. 1998; Rossano et al. 1999; Dunlap and Sibley 2004; Giuli et al. 2002, 2010a, b). Tektites usually experienced aerodynamic transport and can be deposited at great distances (up to several $100 \mathrm{~km}$ ) from the source crater (Glass et al. 1979). Generally, several morphologically different types of tektites may be recognized:

1. most common are the splash-form tektites, found in each of the known strewn fields; they are masses several $\mathrm{cm}$ in size glasses with rounded shapes (spheres, discs, bars, dumbells, teardrop) resulting from their rotational motion when still molten (Elkins-Tanton et al. 2003).

2. aerodynamically shaped tektites (flanged tektites) are button-like objects occurring exclusively in Australia;

3. Muong Nong-type tektites, named after the city of Muong Nong in Laos where they were first described by Lacroix (1935). Typical features of the archetype Muong Nong-type tektites include blocky shape, highly variable size and weight, layered structure, high content of crystalline inclusions (Glass 1970a, b, 2000) and high porosity. Chemical characteristics that distinguish the Muong Nong-type tektites from splashform counterparts include an overall chemical heterogeneity, high volatile trace element abundances (Koeberl 1992)

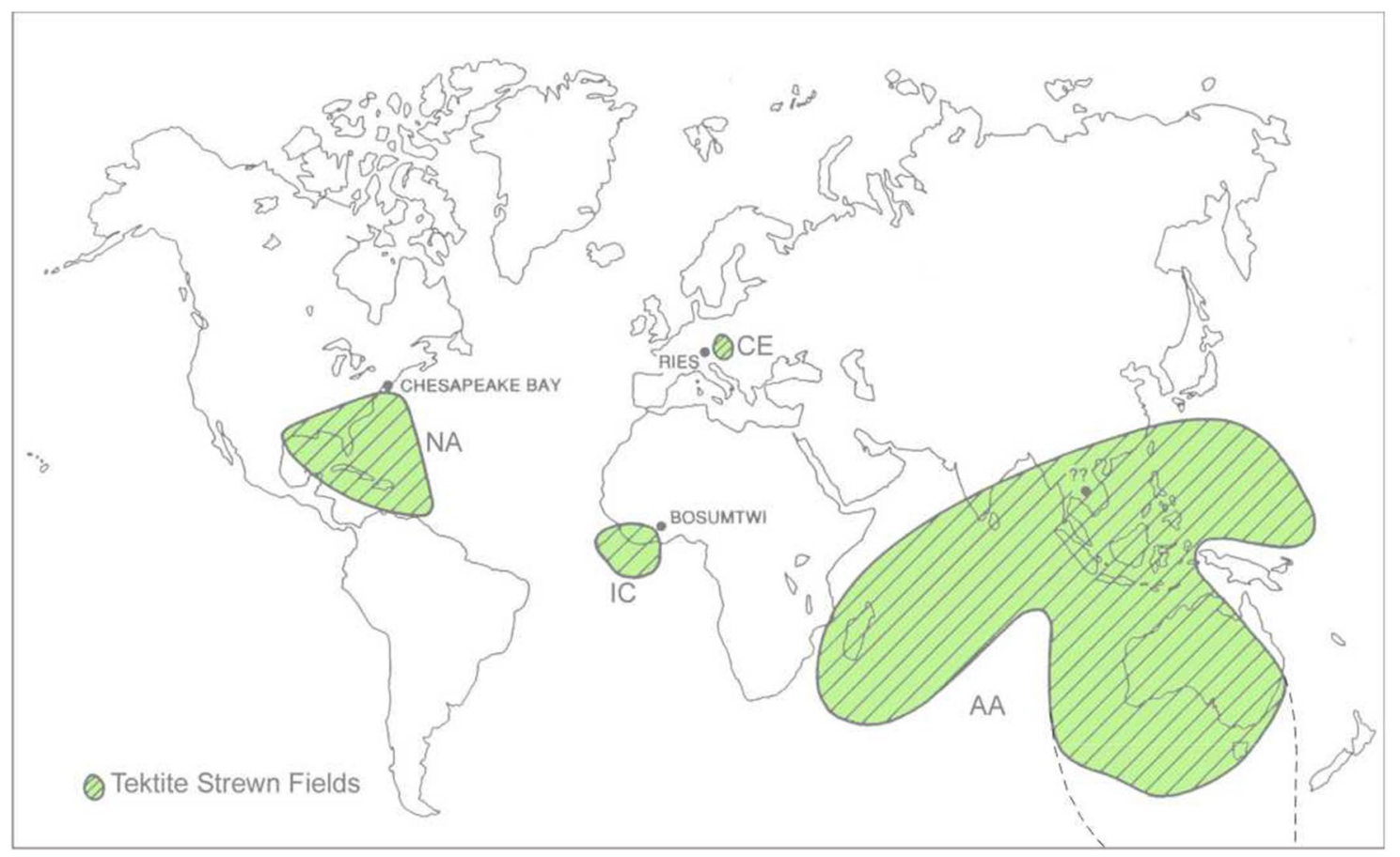

Fig. 1 Extent of the tektite strewn fields so far known (From Montanari and Koeberl 2000, modified). The Australasian strewn field has been modified (dashed line) after the microtektite find reported in Folco et al. (2009). New occurrence of tektites in Belize (Hildebrand et al. 1994), Uruguay and Siberia (Deutsch et al. 1997) are not reported as the extent of the strewn field is not yet known 
and relatively higher water content (Koeberl and Beran 1988).

4. micro-tektites display similar shapes as splash form tektites but are $<1 \mathrm{~mm}$ thick;

A number of studies have already been published on the iron oxidation state of tektites fields using a variety of wet chemical and spectroscopic techniques, and they generally agree on finding a $\mathrm{Fe}^{3+} /\left(\mathrm{Fe}^{2+}+\mathrm{Fe}^{3+}\right)$ ratio $<0.15$ (Fudali et al. 1987; Dunlap et al. 1998; Rossano et al. 1999; Dunlap and Sibley 2004; Giuli et al. 2002, 2010a, b). No significant variations of the $\mathrm{Fe}$ oxidation state have been found between the four best known strewn fields (Australasian, Ivory Coast, Central European, and North American). Also newly discovered tektites from Belize display similar Fe oxidation states (Giuli et al. 2014a). As these values are much lower than those of typical target rocks on the Earth surface, a variety of mechanism have been proposed in order to explain the reduction of iron from mostly trivalent to predominantly divalent (See Lukanin and Kadic 2007 and references therein). However, despite most proposed mechanisms invoke a role of the high temperature in the reduction process, no consensus has been found yet on the causes of iron reduction.

Studies on the microtektites iron oxidation state are scarcer because of the small mass of the samples which hinders the use of wet chemical analyses and poses some limitations on the use of spectroscopic techniques. However, the use of X-ray Absorption Technique (XAS) offers the opportunity to estimate the $\mathrm{Fe}^{3+} /\left(\mathrm{Fe}^{2+}+\mathrm{Fe}^{3+}\right)$ ratio with a good accuracy (Wilke et al. 2001; Jackson et al. 2005; Giuli et al. 2002, 2011) even for small and diluted samples. This technique offers thus a good opportunity to compare iron oxidation states determined for a variety of samples with different sizes and $\mathrm{Fe}$ contents. $\mathrm{Fe}^{3+}$ / $\left(\mathrm{Fe}^{2+}+\mathrm{Fe}^{3+}\right)$ ratio of microtektites from the Australasian and Ivory Coast strewn fields range from 0.02 to $0.22 \pm 0.05$ and 0.03 to $0.17 \pm 0.05$, respectively (Giuli et al. 2013). Microtektites from these strewn fields display similar values to their macroscopic counterparts. However, $\mathrm{Fe}^{3+} /\left(\mathrm{Fe}^{2+}+\mathrm{Fe}^{3+}\right)$ ratio of microtektites from the north American Strewn field is significantly higher than that of North American tektites, and has been found to range between 0.02 and $0.61 \pm 0.05$ (Giuli et al. 2013). In particular, a marked increase of the iron oxidation state has been found with distance from the source crater (Fig. 2). A possible explanation may involve formation of microtektites with $\mathrm{Fe}$ oxidation state and coordination number similar to that of tektites and Trinity glass (a glass formed by high-temperature melting of desert sand during the first atomic bomb test at the Trinity site; see Glass et al. 1988; Giuli et al. 2010b) and subsequent oxidation when still molten.
Systematic variation of the Fe oxidation state of microtektites with distance from the source crater has not been found for other strewn fields where microtektites have been reported. Even in the case of microtektites from the Australasian strewn field (by far the largest tektite strewn field on the Earth surface) that have been found on the Transantarctic Mountains (Folco et al. 2009, 2010, 2011) at about $11,000 \mathrm{~km}$ from the putative location of the source crater, no significant increase of the iron oxidation state has been found with respect to Australasian tektites (Giuli et al. 2014 b) with $\mathrm{Fe}^{3+} /\left(\mathrm{Fe}^{2+}+\mathrm{Fe}^{3+}\right)$ ratios determined for 29 microtektites ranging from 0 to $0.1 \pm 0.05$.

XAS data suggest that the iron oxidation state in the microtektite parent melt could still be modified during ejection and/or transport as observed in the case of North American strewn field microtektites, but not in the Australasian and Ivory Coast microtektites. If we assume that microtektite-forming melt droplets were strongly reduced similarly to tektites (i.e., with dominantly divalent $\mathrm{Fe}$ ) during formation in all of the above-cited cases, future work should be focused on modeling temperature during transport, water content of the melt, and volatile content and redox condition of the medium in which microtektite molten droplets traveled.

\section{Water content of tektites and microtektites}

Water content of silicate melts is an important parameter in affecting melt density and viscosity. In particular, viscosity can change by several orders of magnitude according to water content. Thus the accurate determination of the water content in the just formed melt and of the water solubility of that melt are extremely important parameters in the hope of modelling the melt behaviour from its formation to the formation of glass or crystalline impact-melt rock.

A number of studies determined the tektite water content by Fourier transformed infrared spectroscopy (FTIR). The determined water content in tektites from the four best known strewn fields and the newly discovered Belize tektites range from $20 \mathrm{ppm}$ to about $500 \mathrm{ppm}$ (Gilchrist et al. 1969; Koeberl and Beran 1988; Beran and Koeberl 1997; Watt et al. 2011; Giuli et al. 2013). These data led to the general agreement that the high temperatures to which melt droplets were subjected during impact melting were responsible for the very low water content of tektites compared to water content of terrestrial target rocks. On the other hand, combination of water content data and volatile metal concentration point to a more complex view which has to take into account not only the peak temperatures of the impact produced melts, but also their cooling history; in particular, the possibility that impact produced melts responsible for the tektite formation travel embedded in an ejecta cloud whose composition and thermal 
Fig. 2 Trivalent Fe fraction of the NA microtektites as a function of the distance between the collection site (reported in the legend) and the source crater (Chesapeake Bay impact structure). A marked increase of the trivalent $\mathrm{Fe}$ at increasing distance from the crater is evident. From Giuli et al. (2013) modified

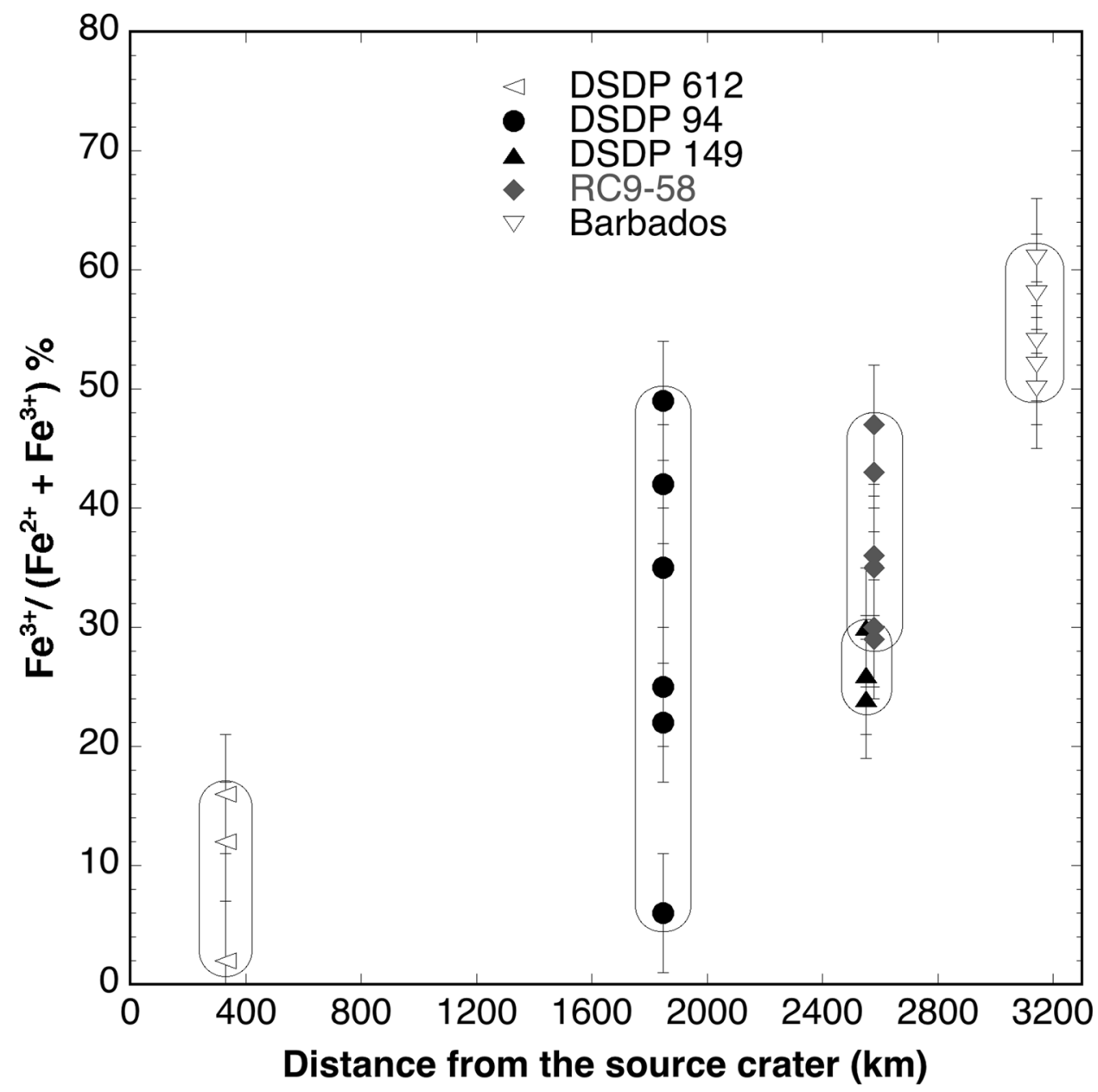

history greatly affect water content of these melts (see, for example Watt et al. 2011 and references therein).

On the side of microtektites, there are much fewer studies of their water content due to reduced availability of fresh material and to the experimental difficulties of measuring low water content in spherules just few hundreds micrometers wide. Folco et al. (2009) determined water content of microtektites found in the Transantarctic Mountains by means of secondary ion mass spectroscopy (SIMS) finding concentrations ranging from 28 to $206 \mathrm{ppm}$. These values compare very well with those of australasian microtektites analysed with the same technique in the same paper (from 20 to 246 ppm). Similarly, other microtektites from the North American Strewn field by means of micro FTIR show water content ranging from 34 to $455 \mathrm{ppm}$ in good agreement with five tektites from the same strewn field analysed in the same conditions (with water content ranging from 158 to 512 ppm (Giuli et al. 2013).

\section{Discussion and conclusions}

Tektites and microtektites have been the subject of so many geochemical studies in the past because of the glimpse they could provide on the formation conditions of impact melt. Despite they offer only a partial and limited view of the complexity of the processes operating during impact cratering and impact melt formation, still they represent the melt formed at the very initial stages of shock-metamorphism during impact and thus offer a precious window on the contact stage of impact cratering.

Low $\mathrm{Fe}^{3+} /\left(\mathrm{Fe}^{2+}+\mathrm{Fe}^{3+}\right)$ ratio and low water content are now commonly accepted to be characteristic of tektites and most microtektites. These feature, together with isotopic signatures, can be fruitfully used to distinguish tektites/microtektites from terrestrial volcanic glasses.

Despite it could be tempting to use determined $\mathrm{Fe}^{3+} /$ $\left(\mathrm{Fe}^{2+}+\mathrm{Fe}^{3+}\right)$ ratios and water content to constrain temperature and redox conditions during the first stages of impact 
melting, it must be kept in mind that, at least for microtektites, their iron oxidation state can be substantially modified during transport. This raises the question if microtektites should be considered the microscopic analog of tektites or if some differences may exist in their formation and/or transport mechanism.

Moreover, the fact that North American microtektite show an increase of the Fe oxidation state (within $3200 \mathrm{~km}$ distance from the source crater) whereas Australasian microtektites do not (within ca. 11,000 km distance from the putative crater location) suggest marked differences in the transport of these microtektites. The Fe redox state of a melt depends on oxygen fugacity, temperature, pressure, and melt composition (see e.g., Moretti and Ottonello 2003 and references therein). Moreover, also kinetics of Fe oxidation and its relation to temperature and composition of the melt (especially water content) must be taken into account. The relatively high range of $\mathrm{Fe}$ redox states found in NA microtektites, being not related to melt chemistry, could be possibly related to mechanisms acting during transport (e.g., in a more oxidizing medium than in the case of Australasian and Ivory Coast microtektites).

The medium in which tektites and/or microtektites travel is an often overlooked aspect of impact models. However it is the author opinion that a knowledge of the transport conditions of tektites and microtektites would greatly help in better deciphering their formation conditions. In this context, a larger dataset on Fe redox ratio and water content of microtektites, as well as new experimental constrains on Fe redox ratio and water solubility of silicate melts at extreme conditions, and on the kinetics of their variations, could help also to further improve physical models on melt formation and transport during impact cratering events.

Acknowledgements Constructive criticism and careful suggestions by an anonymous referee and by Christian Koeberl are greatly appreciated.

\section{References}

Alvarez W, Claeys P, Kieffer SW (1995) Emplacement of CretaceousTertiary boundary shocked quartz from Chicxulub crater. Science 269:930-935

Artemieva NA, Wunnemann K, Krien F, Reimold WU, Stoffler D (2013) Ries crater and suevite revisited-observations and modeling, part II: modeling. Meteorit Planet Sci 48:590-627

Beran A, Koeberl C (1997) Water in tektites and impact glasses by Fourier-transformed infrared spectrometry. Meteorit Planet Sci $32: 211-216$

Dence MR (1971) Impact melts. J Geophys Res 76:5552-5565

Deutsch A, Ostermann M, Masaitis VL (1997) Geochemistry and neodymium-strontium isotope signature of tektite-like objects from Siberia (Urengoites, South Ural Glass). Meteorit Planet Sci 32:679-686
Dunlap RA, Sibley ADE (2004) A Mössbauer effect study of Fe site occupancies in Australasian tektites. J Non-Cryst Solids 337:36-41

Dunlap RA, Eelman DA, MacKay GR (1998) A Mössbauer effect investigation of correlated hyperfine parameters in natural glasses (tektites). J Non-Cryst Solids 223:141-146

Elkins-Tanton LT, Aussillous P, Bico J, Quéré D, Bush JWM (2003) A laboratory model of splash form tektites. Meteorit Planet Sci 38:1331-1340

Folco L, D'Orazio M, Tiepolo M, Tonarini S, Ottolini L, Perchiazzi N, Rochette P, Glass BP (2009) Transantarctic mountain microtektites: geochemical affinity with Australasian microtektites. Geochim Cosmochim Acta 73:3694-3722

Folco L, Glass BP, D’Orazio M, Rochette P (2010) A common volatilization trend in Transantarctic Mountain and Australasian microtektites: implications for their formation model and parent crater location. Earth Planet Sci Lett 293:135-139

Folco L, Bigazzi G, D’Orazio M, Balestrieri ML (2011) Fission track age of the Transantarctic Mountain microtektites. Geochim Cosmochim Acta 75:2356-2360

French BM (1988) Traces of catastrophe: a handbook of shock-metamorphic effects in terrestrial meteorite impact structures. LPI Contribution No. 954. Lunar and Planetary Institute, Houston, p 120

French BM, Short NM (eds) (1968) Shock metamorphism of natural materials. Mono Book Corporation, Baltimore, p 644

Fudali RF, Dyar MD, Griscom DL, Schreiber D (1987) The oxidation state of iron in tektite glass. Geochim Cosmochim Acta 51:2749-2756

Gibson RL, Reimold WU (2010) Introduction: impact cratering and planetary studies-a fifty-year perspective. In: Large meteorite impacts and planetary evolution IV. The Geological Society of America, Special Paper 465, pp vii-xii. doi:10.1130/2010.2465(00)

Gilchrist J, Thorpe AN, Senftle FE (1969) Infrared analysis of water in tektites and other glasses. J Geophys Res 74:1475-1483

Giuli G, Pratesi G, Paris E, Cipriani C (2002) Fe local structure in tektites by EXAFS and high resolution XANES spectroscopy. Geochim Cosmochim Acta 66:4347-4353

Giuli G, Paris E, Pratesi G, Koeberl C, Cipriani C (2003) Iron oxidation state in the Fe-rich layer and silica matrix of Libyan desert glass: a high-resolution XANES study. Meteorit Planet Sci 38:1181-1186

Giuli G, Eeckhout SE, Paris E, Koeberl C, Pratesi G (2005) Iron oxidation state in impact glass from the K/T boundary at Beloc, Haiti, by high-resolution XANES spectroscopy. Meteorit Planet Sci 40:1575-1580

Giuli G, Eeckhout SG, Koeberl C, Pratesi G, Paris E (2008) Yellow impact glass from the K/T boundary at Beloc (Haiti): XANES determination of the Fe oxidation state and implications for formation conditions. Meteorit Planet Sci 43:981-986

Giuli G, Eeckhout SG, Cicconi MR, Koeberl C, Pratesi G, Paris E (2010a) Iron oxidation state and local structure in North American tektites. In: Reimold WU, Gibson R (eds) Large meteorite impacts and planetary evolution IV. Geological Society of America Special Paper 465, Boulder, CO, USA, pp 645-652

Giuli G, Pratesi G, Eeckhout SG, Koeberl C, Paris E (2010b) Iron reduction in silicate glass produced during the 1945 nuclear test at the trinity site (Alamogordo, New Mexico, USA). In: Reimold WU, Gibson R (eds) Large meteorite impacts and planetary evolution IV. Geological Society of America Special Paper 465, Boulder, CO, USA, pp 653-662

Giuli G, Paris E, Hess KU, Dingwell DB, Cicconi MR, Eckhout SG, Fehr KT, Valenti P (2011) XAS determination of the Fe local environment and oxidation state in phonolite glasses and implications for the viscosity of silicate melts. Am Mineral 96:631-636 
Giuli G, Cicconi MR, Eeckhout SG, Koeberl C, Glass BP, Pratesi G, Cestelli-Guidi M, Paris E (2013) North-American microtektites are more oxidized than tektites. Am Mineral 98:1930-1937

Giuli G, Cicconi MR, Stabile P, Trapananti A, Pratesi G, Cestelli-Guidi M, Koeberl C (2014a) New data on the Fe oxidation state and water content of Belize tektites. In: 45th Lunar Planet. Sci., \#2322 (abstr.)

Giuli G, Cicconi MR, Eeckhout SG, Paris E, Folco L (2014b) Australasian microtektites from Antarctica: determination of the iron oxidation state. Meteorit Planet Sci 49:696-705

Glass BP (1970a) Crystalline inclusions in Muong Nong-type tektite. Meteoritics 5:199-200

Glass BP (1970b) Zircon and chromite crystals in a Muong Nong-type tektite. Science 169:766-769

Glass BP (1990) Tektites and microtektites: key facts and inferences. Tectonophysics 171:393-404

Glass BP (2000) Relict zircon inclusion in Muong Nong-Type Australasian tektites: implications regarding the location of the source crater. In proceedings of 31st Annual Lunar and Planetary Science Conference, Houston, TX, USA, 13-17 March 2000

Glass BP, Swincki MB, Zwart PA (1979) Australasian, vory Coast and North American tektite strewn fields: size, mass and correlation with the geomagnetic reversal and other earth events. Proc Lunar Planet Sci Conf 1979:2535-2545

Glass BP, Senfltle FE, Muenow DW, Aggrey KE, Thorpe AN (1988) Atomic bomb glass beads: tektite and microtektite analogs. In: proceedings, Second International Conference on Natural Glasses, Prague, September, 1987, 361-369

Grieve RAF, Cintala MF (1992) An analysis of differential impact meltcrater scaling and implications for the terrestrial impact record. Meteoritics 27:526-538

Grieve RAF, Langenhorst F, Stoffler D (1996) Shock metamorphism of quartz in nature and experiment: II. Significance in geoscience. Meteorit Planet Sci 31:6-35

Hildebrand AR, Moholy-Nagy H, Koeberl C, May L, Senftle F, Thorpe AN, Smith PE, York D (1994) Tektites found in the ruins of Tikal, Guatemala. In: 25th Lunar Planet. Sci. 549-550

Jackson WE, Farges F, Yeager M, Mabrouk PA, Rossano S, Waychunas GA, Solomon EI, Brown GEJR (2005) Multi-spectroscopic study of $\mathrm{Fe}(\mathrm{II})$ in silicate glasses: implications for the coordination environment of $\mathrm{Fe}(\mathrm{II})$ in silicate melts. Geochim Cosmochim Acta 69:4315-4332

Koeberl C (1986) Geochemistry of tektites and impact glasses. Annu Rev Earth Planet Sci 14:323-350

Koeberl C (1992) Geochemistry and origin of Muong Nong-type tektites. Geochim Cosmochim Acta 56:1033-1064

Koeberl C (1994) Tektite origin by hypervelocity asteroidal or cometary impact: target rocks, source craters, and mechanisms. In: Dressler BO, Grieve RAF, Sharpton VL (eds) Large meteorite impacts and planetary evolution. Geol. Soc. Amer. Spec. Paper 293, Boulder, pp 133-151

Koeberl C, Beran A (1988) Water content of tektites and impact glasses and related chemical studies. In: 18th Lunar and Planet. Sci. Conf., LPI-Cambridge University Press, 403-408

Koeberl C, MacLeod KG (2002) Catastrophic events and mass extinctions: impacts and beyond. Geological Society of America Special Paper 356

Koeberl C, Martinez-Ruiz FC (2003) Impact markers in the stratigraphic record. Impact studies. Springer, Berlin. doi:10.1007/978-3-642-55463-6
Koeberl C, Sigurdsson H (1992) Geochemistry of impact glasses from the K/T boundary in Haiti: relation to smectites, and a new type of glass. Geochim Cosmochim Acta 56:2113-2129

Koeberl C, Nishiizumi K, Caffee MW, Glass BP (2015) Beryllium-10 in individual australasian microtektites and origin of tektites. Meteorit Planet Sci 50(Suppl 1):5187

Lacroix A (1935) Les tectites sans formes figures de l'Indochine. Compt Rend Acad Sci Paris 200:2129-2132 (in French)

Lukanin OA, Kadic AA (2007) Decompression mechanism of ferric iron reduction in tektite melts during their formation in the impact process. Geochem Int 45:857-881

Ma P, Aggrey K, Tonzola C, Schnabel C, de Nicola P, Herzog GF, Wasson JT, Glass BP, Brown L, Tera F, Middleton R, Klein J (2004) Beryllium-10 in Australasian tektites: constraints on the location of the source crater. Geochim Cosmochim Acta 68:3883-3896

Melosh HJ (1989) Impact cratering: a geologic process. Oxford University, New York, p 245

Montanari A, Koeberl C (2000) Impact stratigraphy: the Italian record. Lecture notes in earth sciences, vol 93. Springer, Berlin, p 364

Moretti R, Ottonello G (2003) Polymerization and disproportionation of iron and sulfur in silicate melts: insights from an optical basicitybased approach. J Non-Cryst Solids 323:111-119

O'Keefe JA (1976) Tektites and their origin. Elsevier, Amsterdam, p 254

Pierazzo E, Melosh HJ (2000) Melt production in oblique impacts. Icarus 145:252-261

Ritter X, Deutsch A, Berndt J, Robin E (2015) Impact glass spherules in the Chicxulub K-Pg event bed at Beloc, Haiti: alteration patterns. Meteorit Planet Sci 50:418-432

Rossano S, Balan E, Morin G, Bauer JP, Calas G, Brouder C (1999) ${ }^{57} \mathrm{Fe}$ Mössbauer spectroscopy of tektites. Phys Chem Miner 26:530-538

Schulte P, Alegret L, Arenillas I, Arz JA, Barton PJ, Bown PR, Bralower TJ, Christeson GL, Claeys P, Cockell CS, Collins GS, Deutsch A, Goldin TJ, Goto K, Grajales-Nishimura JM, Grieve RAF, Gulick SPS, Johnson KR, Kiessling W, Koeberl C, Kring DA, MacLeod KG, Matsui T, Melosh J, Montanari A, Morgan JV, Neal CR, Nichols DJ, Norris RD, Pierazzo E, Ravizza G, Rebolledo-Vieyra M, Reimold WU, Robin E, Salge T, Speijer RP, Sweet AR, UrrutiaFucugauchi J, Vajda V, Whalen MT, Willumsen PS (2010) The chicxulub asteroid impact and mass extinction at the cretaceouspaleogene boundary. Science 327:1214-1218

Shoemaker EM (1962) Interpretation of lunar craters. In: Koual Z (ed) Physics and astronomy of the Moon. Academic Press, New York, pp 283-359

Stoffler D, Langenhorst F (1994) Shock metamorphism of quartz in nature and experiment: I. Basic observation and theory. Meteoritics 29:155-181

Stöffler D, Artemieva NA, Wünnemann K, Reimold W, Jacob J, Hansen B, Summerson IAT (2013) Ries crater and suevite revisitedobservations and modeling. Part I: observations. Meteorit Planet Sci 48:515-589

Suess FE (1900) Die Herkunft der Moldavite. Jahrb Kais K Geol Reichsanst 50:193-382 (in German)

Watt N, Bouchet RB, Lee CTA (2011) Exploration of tektite formation processes through water and metal content measurements. Meteorit Planet Sci 46:1025-1032

Wilke M, Farges F, Petit PE, Brown GE, Martin F (2001) Oxidation state and coordination of $\mathrm{Fe}$ in minerals: an Fe K-XANES spectroscopic study. Am Mineral 86:714-773 